\section{Carta a um mestre}

Recompor imagens, rever um passado que já tem quase quatro décadas e tentar montar uma seqüência que faça sentido a quem dela ainda ouviu falar pouco... tarefa dificil... mas que envolve ao escrever, mais do que fazer um documento, colocar as impressões de quem viveu próximo e acompanhou - de estudante da primeira turma da Faculdade de Filosofia, Ciências e Letras de Ribeirão Preto a docente com 30 anos já de casa - Um Jovem Professor Belga, cidadão Brasileiro.

Quisera que estas palavras soassem como as de uma carta, dirigida a este Mestre, $o$ Professor André Jacquemin. Sei que é necessário que a história não se perca; conversamos vezes sem conta sobre isto, na sua sala do CPA. Mas, como diz a canção ciso"

"navegar é preciso, viver não é pre-

Mas temos sim que recordar

"Voltar no tempo...

Soltar as amarras que nos prendem ao presente

Evagar onde aporteo pensamento,

Trazendo as lembranças de um tempo que marcou

A construção de uma Faculdade, $e$, nela,

Um curso que, iniciado, implantou principios e saberes

Pela dedicação e competência de jovens

Que se dispuseram a dar o melhor de si

Expandindo o conhecimento advindo de um outro pais".

Urge deixar marcado o que trouxe, plantou e colheu, o que significa dar voz à necessidade premente, neste momento, de ao recriar as situações passadas, lembrar as idéias, os principios e a sua vontade de construir, vinda da terra distante onde nasceu. Em outros termos, é preciso fazer surgir e eternizar a sua presença nesta casa. Portanto, não se iluda Mestre, porque não existe a permissão de partir e de poder ser esquecido!

Era 1966 - A juventude com seu idealismo o fez deixar seu país para se dedicar a um trabalho em terra distante, atraido pelo convite/promessa de um grande visionário, o criador de uma Faculdade mais virtual do que real- Professor Lucien Lison, conterrâneo seu, que dizia aqui existir um campo fértil para 'plantar e colher', para fazer Ciência e também Psicologia (desde que científica).

Esse jovem Mestre aportou com uma bagagem de sonhos/desejos, com uma vontade imensa que transparecia na alegria das aulas, na ausência de recusa de qualquer trabalho/missão por mais incompreensíveis que fossem as situações com que se deparava. (que não eram poucas,professor). E nós, alunos, tínhamos defasagens muito grandes e a cada momento era preciso que criassem novas disciplinas... gerando outras tantas tarefas... Mas, prevalecia sempre o ideal de prover uma formação de excelência.

Seguindo passo a passo, vê-se que sempre houve o borbulhar de idéias novas, e, a distância no tempo permite traçar a linha da sua aceitação gradativa de uma cultura, de um povo, ao lado da entrega constante de sua força de trabalho para construir este Departamento de Psicologia e Educação e esta Faculdade de Filosofia!

Decorridas duas décadas e meia, faltava ainda fazer alguma coisa? Sim, apenas e tão somente firmar no papel 
aquilo que há muito era a realidade da sua atuação: tornar-se brasileiro!!! E você o fez!!!

E os seus Principios, Professor André? Sempre seguidos a risca e dentro de uma Ética de altissimo nivel: Desde a Camaradagem com seus pares; no decorrer dos anos, sua Honestidade como uma constante; a Seriedade no Trabalho; aliada à Retidão de caráter; sobressaindo a Lhaneza no trato; e por fim o Acolhimento, porque o estudante batia na sua porta e era sempre recebido.

Talvez os sonhos/desejos não tenham se realizado da maneira como pretendia; contudo, quem olha o seu trabalho, de um lado vê a semente plantada e regada a Cursos, Exames Orais, Monografias, Defesas; de outro, um Doutorado, uma Livre Docência e um Titular, acompanhados da chefia do Departamento, depois, da Direção de uma Unidade da USP, a Faculdade de Filosofia, Ciências e Letras de Ribeirão Preto, e, por fim, a coordenação do recém criado Programa de Pós-Graduação em Psicologia.

E, há um desfilar imenso de alunos e orientandos que tiveram o privilégio de beber da fonte de sua energia, vivenciaram a relação Mestre x Aprendiz e estão por este mundo afora, agora com a tarefa de multiplicar o que receberam do Professor André Jacquemin.

Ainda, a Pós-Graduação permitiu, uma vez mais, a oportunidade de juntar esforços; sua crença indicava que era preciso construir um Programa, na área da Psicologia que chegasse à marca da 'Excelência'; e é para onde ele caminha, porque o compromisso que instalou permanece, levando a que se 'lute o bom combate', razão porque o Programa de Pós para o qual lançou a pedra fundamental já começa a 'estar pelo mundo'. De início, eram pouquíssimos os recursos e ainda assim, como coordenador, arquitetou e deixou pronta uma primeira infra-estrutura, que permite trabalhar até hoje.São as salas de Seminário, a base administrativa, a necessidade de avaliação dos trabalhos de pesquisa que estavam em andamento- tudo isto é mérito seu, Mestre. Dirse-ia que plantou tão bem, que os céus não permitiram que as sementes se perdessem e elas foram se mantendo e frutificando...

Professor, o senhor honrou todos os seus princípios e é preciso dizer, Professor André: obrigado porque veio, porque permaneceu enfrentando o bom e o ruim desta terra e fez nascerem linhas importantes de pesquisa e extensão que se disseminam por este Brasil afora. Nosso eterno reconhecimento a este Cidadão Brasileiro por opção.

Zélia Maria Mendes Biasoli Alves 